\title{
Efficacy of Gas Purging for Titanium Casting
}

\author{
Kiyoshi TAJIMA, Seijiro MATSUDA, Satoyuki KITAJIMA, Yuki YOKOYAMA, \\ Hiroshi KAKIGAWA and Yoshio KOZONO \\ Department of Materials Science, Kyushu Dental College, \\ 2-6-1 Manazuru, Kokurakita, Kitakyushu 803, Japan \\ ${ }^{1}$ U-WA TECH CORP., 1-5-1 Sendai, Tobata, Kitakyushu 804, Japan
}

Received July 28, 1994/Accepted October 19, 1994

\begin{abstract}
Oxygen density in the melting atmosphere, oxygen uptake, hardness and castability of pure titanium castings were examined to evaluate the efficacy of gas purging in reducing contamination from the melting atmosphere and mold, using a newly developed titanium casting machine in which the double purging process is systematized. The adoption of a double purging operation resulted in an extremely low oxygen density in the melting atmosphere, followed by extremely low oxygen uptake in the casting when compared with the conventional titanium casting machine. When the purging operation was used, the surface hardness was markedly reduced, although there was no difference in castability. From these results, it was suggested that the newly developed titanium casting machine with the double purging operation could produce better titanium castings with less contamination due to the mold and gas impurities in melting atmosphere.
\end{abstract}

Key words: Dental casting, Titanium, Casting machine

\section{INTRODUCTION}

Over the past decade, significant developments have been made in the dental casting of titanium and its alloys, and several casting systems are now available commercially ${ }^{1-3}$. Although an inert atmosphere is commonly used in those systems ${ }^{1}$, titanium and its alloys are often susceptible to contamination with atmospheric gas and mold components during melting and casting. As titanium is highly reactive at high temperatures, it can easily be oxidized and dissolve such elements as oxygen, nitrogen and hydrogen.

Several investigators ${ }^{4-7)}$ have demonstrated that such potential contamination from the melting atmosphere might easily cause the deterioration of mechanical properties in titanium castings. Yoneyama et $a l .{ }^{4)}$ reported the effect of the vacuum degree in the melting chamber on the mechanical properties of pure titanium castings, and Hamanaka ${ }^{1)}$ described that the most efficient method for replacing the air in the chambers with an inert gas is repeating the evacuation-a gas flooding process. Tamaki et al. ${ }^{5}$ ) also showed that increasing the number of repetitions of an exhaust and argon gas inflow process is more effective in producing titanium castings with less contamination.

A new titanium casting machine was developed, which has two significant characteristics of a double gas purging operation and a highly differential gas pressure for casting. In this study, the efficacy of purging was examined in terms of oxygen density in the melting atmosphere, oxygen uptake and hardness of pure titanium castings, and castability of titanium. 


\section{MATERIALS AND METHODS}

Fig. 1 shows the external view of the newly developed casting machine* for titanium and its alloys (Code: MC). It has a two-chamber structure, consisting of an upper melting chamber and a lower casting chamber, and is principally a type of argon-arc melting and suctionargon gas pressure casting with a low temperature mold. The schematic operation diagram is shown in Fig. 2. The main features of the machine are as follows: (1) the chambers and mold are dried and purged of air and gas impurities by the double purging process consisting of evacuation of the chambers through the mold and subsequent argon gas inflow twice, and (2) a highly differential casting pressure $\left(7 \mathrm{kgf} / \mathrm{cm}^{2}\right.$ at maximum).

Oxygen density in the melting atmosphere was measured through each step of the

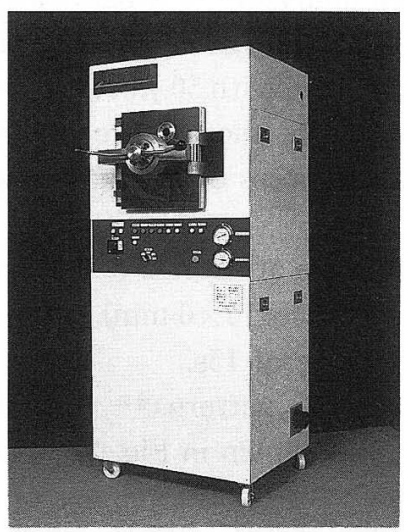

Fig. 1 External view of the newly developed casting machine.

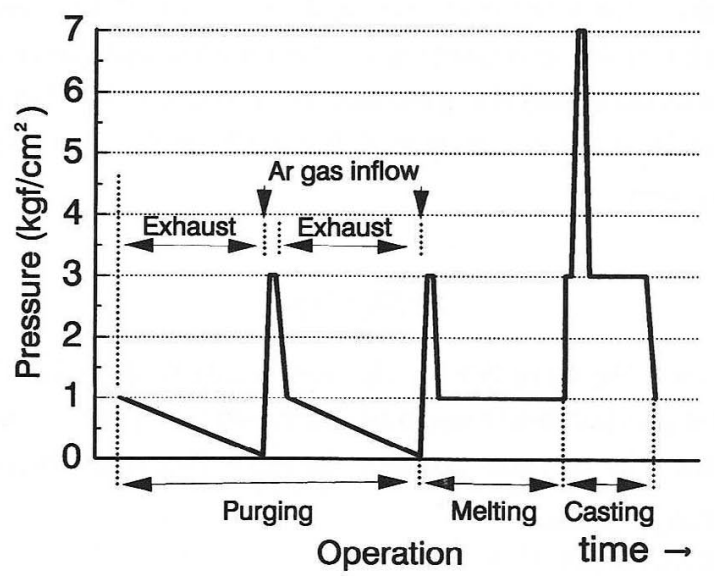

Fig. 2 Schematic diagram of pressurizing operation for the melting chamber of the machine.

* MYCAST, U-WA TECH CORP., Kitakyushu, Japan 


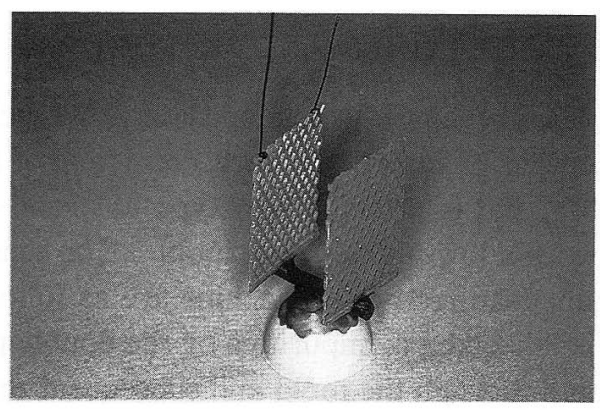

Fig. 3 Wax pattern for castability test.

purging operation using an oxygen analyzer**, which was set in the melting chamber of a prototype of the casting machine $\mathrm{MC}$. Oxygen content in titanium castings $\left(3^{ø} \times 20 \mathrm{~mm}\right)$, the surface of which was slightly sandblasted with $50 \mu \mathrm{m} \mathrm{Al}_{2} \mathrm{O}_{3}$, was determined with a nitrogen/ oxygen determinator\#. For comparison, another arc-melting and suction-pressure casting machine ${ }^{\#}$ (Code : CA) which uses a process of evacuation and subsequent argon gas inflow for once, was used.

Hardness measurements were made at several points from the surface to the interior on the cross-section of titanium castings $(10 \times 10 \times 6 \mathrm{~mm})$, using a Vickers microhardness tester ${ }^{œ}$ with a load of $500 \mathrm{~g}$ and a loading time of $15 \mathrm{~s}$.

For the castability test, wax mesh patterns ${ }^{\circledR}(26 \times 35 \mathrm{~mm})$ with 119 segments were prepared with or without air vents, as shown in Fig. 3. The castability was evaluated with the ratio of cast titanium segments to the total number of segments in the wax pattern.

Pure titanium ingots $\$$, JIS grade 2 (oxygen content; $1150 \mathrm{ppm}$ from the inspection certificate of the manufacturer) and a phosphate-bonded investment material ${ }^{\$ \$}$ specified for the casting machine MC were used for casting. The investment material was mixed, heated according to the manufacturer's instructions, and then cooled to room temperature before casting. In casting with $\mathrm{CA}$ for comparison of the oxygen uptake in the casting, an investment specified for CA was used and the preparation of the mold followed the manufacturer's instructions. Three specimens were prepared for each of the oxygen determination, hardness test and castability test.

\section{RESULTS}

Oxygen density in the melting chamber of the new casting machine MC was $34 \mathrm{ppm}$ at a minimum during the first gas purging step, and fell down to $7 \mathrm{ppm}$ at the second purging step. Fig. 4 shows the changes in oxygen content in pure titanium casting with the purging

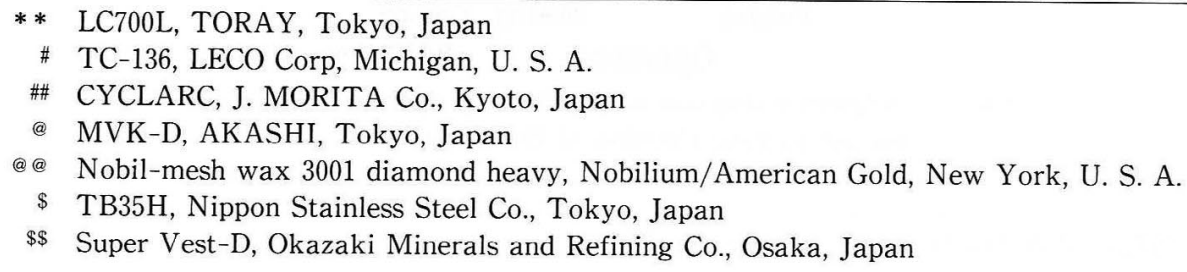


operation, together with content when the other casting machine CA was used. The oxygen uptake in the casting was more than $120 \mathrm{ppm}$ when the casting was made without purging. This was significantly decreased by the purging operation, being about $30 \mathrm{ppm}$ after the single purging and $6 \mathrm{ppm}$ after the double purging on average. Although there was no significant difference in the oxygen content between the single and double purging operations, the deviation in the content became markedly smaller with the double purging. In the casting machine $\mathrm{CA}$, the oxygen uptake was about $100 \mathrm{ppm}$.

Fig. 5 shows the microhardness distribution of the castings. The outermost surface was harder than the interior, where hardness reached constant values. Such surface hardening was marked when the non-purging operation was used, while there was little difference between the single and double purging operations.

The castabilities of titanium under the different conditions are shown in Fig. 6 . No improvement in castability was observed by repeating the purging operation independently of

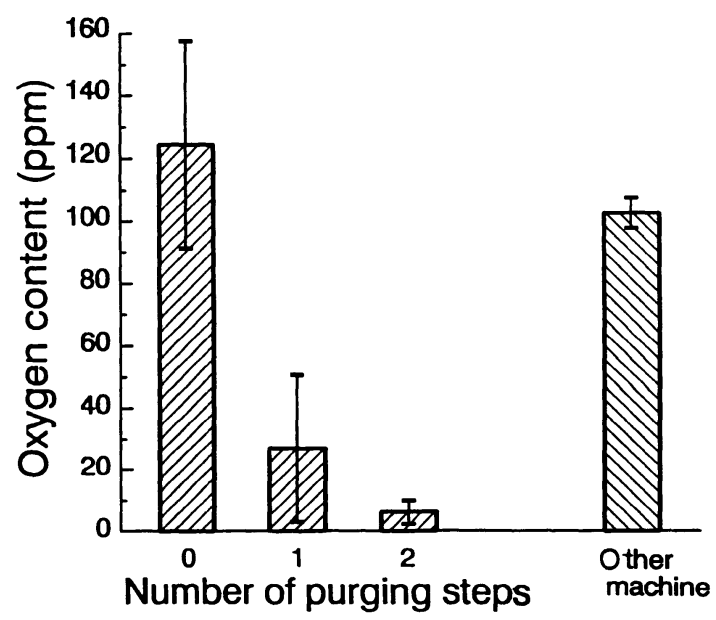

Fig. 4 Oxygen content in the castings obtained after purging operation.

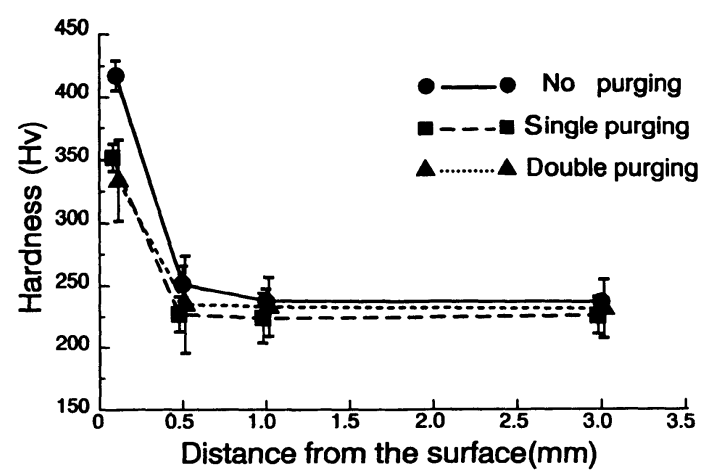

Fig. 5 Hardness distribution of the castings obtained after purging operation. 


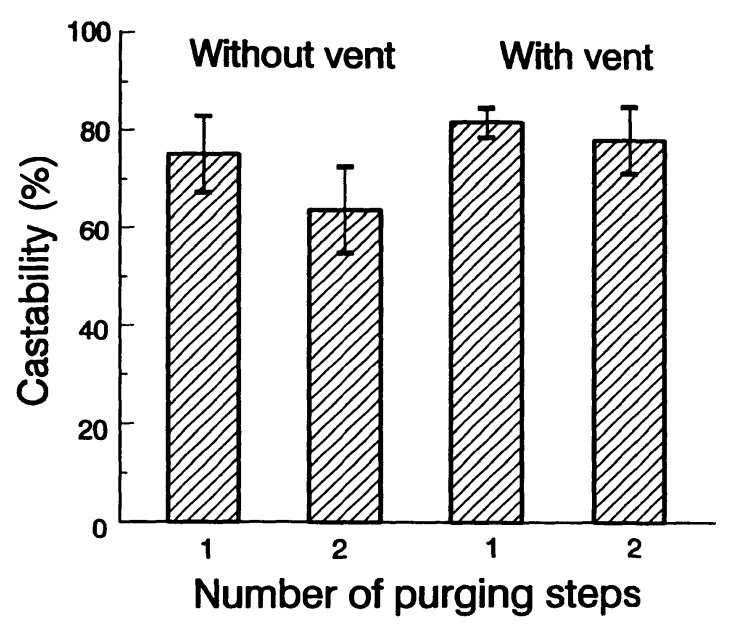

Fig. 6 Castability of titanium.

the addition of air venting.

\section{DISCUSSION}

A common method for preventing oxidation or other atmospheric attack in titanium casting is to employ an inert gaseous atmosphere in the melting chamber or in all chambers. Several investigators ${ }^{4-6)}$ have suggested that it would be important to repeat a series of evacuation and argon gas inflow processes as the residual air due to insufficient air exhaust or replacement with argon gas might cause contamination during melting and casting, resulting in the embrittlement of titanium castings. In the newly developed casting machine $\mathrm{MC}$, the double gas purging system is incorporated, in which a cycle of evacuation followed by argon gas inflow is repeated twice. It was found that the oxygen in the melting chamber could be reduced to $34 \mathrm{ppm}$ by the first purging and to as low as $7 \mathrm{ppm}$ by the second purging in this system. As the purging process is performed through the mold in the casting chamber, it may also be effective for purging the air in the mold as well as for drying the mold. Consequently, the oxygen uptake in the resultant titanium casting could be significantly reduced. The oxygen content in the casting was $30 \mathrm{ppm}$ when the single purging operation was applied and only $6 \mathrm{ppm}$ when the double purging operation was applied. The process in the conventional titanium casting machines that the chamber is once evacuated and filled with argon gas prior to melting the ingot may be analogous in principle to the single purging process in MC. However, the oxygen uptake in the casting with one of the conventional casting machine CA was much higher than that obtained after the single purging with MC. It has been reported that the potential contamination of the casting would be affected by the vacuum degree in the melting chamber due to the use of different vacuum pumps $^{4-6)}$ and argon gas flow rate ${ }^{7)}$. In addition to such factors, the low mold temperature employed in MC may have favorably restrained the reaction of titanium with oxygen. The double purging operation appeared to be sufficient for minimizing oxygen contamination in the melting and 
casting chambers in $\mathrm{MC}$, differing from the results of previous reports using the other casting machines ${ }^{4,5}$.

Generally, the mechanical properties, of cast titanium are greatly affected by the oxygen content in the casting ${ }^{8)}$; the tensile strength increases and elongation decreases with increases in oxygen content. Hamanaka et $a l^{9)}$ and Yoneyama et $a l .^{{ }^{4)}}$ reported that the tensile strength and elongation of cast titanium varied with use of different casting machines and different vacuum degrees, and that this might be partly attributed to the different residual oxygen contents in the melting atmosphere causing oxidation and oxygen uptake. The existence of a hardened or reacted layer in the surface of titanium castings has also been reported $^{8,10-14)}$. This layer has been found to embrittle the casting because it is hardened by oxygen uptake and may include cracks ${ }^{10,11)}$, and it is considered to be materially undesirable for titanium casting ${ }^{14)}$. In the present study, surface hardening of the casting was observed from the hardness test, and the surface hardening was marked when no purging operation was applied. A significant decrease in the surface hardness was found in castings obtained after the first purging operation, although no effect of purging appeared on the internal hardness of the casting. The hardness showed no further decrease by the second purging operation. The formation of the reacted layer of the casting in the mold is attributed to the contact with the investment, and can be diminished by lowering the mold temperature or selecting the investment composition ${ }^{5,10-13)}$. Oxygen may also contribute to the formation of the reacted layer ${ }^{11}$. As the low temperature mold is employed in the casting system of MC, it is considered that the reaction of the molten titanium with the mold and atmosphere may be inherently restrained to some degree. Moreover, the purging operation could effectively reduce the oxygen density in the melting and casting atmosphere as well as the oxygen uptake in the casting. Although it is not known whether the oxygen in the atmosphere during melting and casting may react with titanium primarily from surface oxidation or solid solution, or may partly control the rate of reaction of molten titanium with the mold, the reduction in oxygen content in turn resulted in a significant decrease in surface hardness. However, the purging operation showed no further decrease in the hardness. This indicates that changes in oxygen content below the level of $30 \mathrm{ppm}$ would have no practical effect on the hardness. On the other hand, the hardened layer was still observed in the surface area even although the oxygen content in the casting was reduced to as low as $6 \mathrm{ppm}$. The investment material used was of a phosphate-bonded type specified for the casting machine $\mathrm{MC}$, and the hardened layer might have formed by the reaction with silicon ${ }^{15)}$ or some other components from the investment mold. The purging operation employed in MC was found to be sufficient for minimizing the change in hardness, although some reaction with the mold might be unavoidable as long as the phosphate-bonded investment is used.

The castability of molten titanium has been considered to be affected by contamination due to the mold ${ }^{16)}$. Tamaki et $a l .{ }^{17)}$ and Matsuda et al. ${ }^{18)}$ reported that the newly developed casting machine MC could produce satisfactory titanium castings in appearance with good castability and less external casting defect for simple plate or clinical metal framework for denture base use. In the present study, the effect of the repeated purging operations on castability was examined using mesh patterns. The results showed no clear difference in castability between the single and double purging operations. This is probably because the 
casting pressure in $\mathrm{MC}$ was large enough to negate the effect of the purging operation if any.

\section{CONCLUSION}

Oxygen density in the melting atmosphere, oxygen uptake, hardness and castability of pure titanium castings were examined to evaluate the efficacy of the gas purging operation in minimizing contamination from the melting atmosphere and mold, using a newly developed titanium casting machine with a systematic double purging process. Oxygen density in the melting chamber was $34 \mathrm{ppm}$ during the first purging step, and was reduced to as low as 7 ppm by the second purging operation. The oxygen content in the casting tended to decrease with repetition of the purging operation. The new casting machine significantly reduced the oxygen uptake in the casting by the purging operation when compared with the conventional titanium casting machine. When the purging operation was used, the surface hardness was markedly reduced, although there was no difference in castability. From these results, it was suggested that the newly developed titanium casting machine with the double purging operation could produce better titanium castings with less contamination due to components of the mold and gas impurities from the melting atmosphere.

\section{REFERENCES}

1) Hamanaka, H.: Titanium casting-A review of casting machines, Transactions of second international congress on dental materials, 89-96, 1993.

2) Miyazaki, T.: Progress of casting apparatus for titanium, $J$ J Dent Mater 13 Special 23 : 93, 1994. (in Japanese)

3) Hamanaka, H.: The present state of the development in titanium casting machines, $J J$ Dent Mater 13 Special 23 : 94, 1994. (in Japanese)

4) Yoneyama, T., Doi, H., Hara, M. and Hamanaka, H.: Influences on mechanical properties of pure titanium casting. Part 1 Titanium ingots and vacuum degree in the melting chamber, Report of the Institute for Medical \& Dental Engineering 24: 5-10, 1990. (in Japanese)

5) Tamaki, Y., Hotta, Y., Tanaka, H. and Miyazaki, T.: Casting of titanium with calcia investment, $J$ Showa Univ Dent Soc 13: 237-242, 1993. (in Japanese)

6) Hamanaka, H., Doi, H., Kohno, O. Yoneyama T. and Miura, I. : Dental castings of NiTi alloys. Part 3 New casting machine for NiTi alloys and high-fusing base metal alloys, $J J$ Dent Mater 5 (5) : 578 $-586,1986$. (in Japanese)

7) Etchu, Y., Takahashi, K., Sato, M. and Noguchi, H.: Study on the mechanical properties of pure titanium for dental casting. Part 1 Influence of casting conditions, $J$ Tohoku Dent Univ 14 (3) : 130 $-135,1987$. (in Japanese)

8) Taira, M.: Titanium as a dental casting metal-Material characteristics of pure titanium and titanium alloys and their composition with other dental casting alloys-, QDT 13 (1): 51-60, 1988. (in Japanese)

9) Hamanaka, H., Doi, H., Kohno, O. Yoneyama, T. and Okuno, O.: Dental casting of titanium and Ni -Ti alloys by a new casting machine, $J$ Dent Res 68 (11): 1529-1533, 1989.

10) Takahashi, J., Kimura, H., Lautenschlager, E. P., Chen Lin, J. H., Moser, J. B. and Greener, E. H.: Casting pure titanium into commercial phosphate-bonded $\mathrm{SiO}_{2}$ investment molds, $J$ Dent Res 69 (12): 1800-1805, 1990.

11) Miyakawa, O., Watanabe, K., Okawa, S., Nakano, S., Kobayashi, M. and Shiokawa, N.: Layered structure of cast titanium surface, Dent Mater J 8 (2): 175-185, 1989.

12) Taira, M., Moser, J. B. and Greener, E. H. : Studies of Ti alloys for dental casting, Dent Mater 5 : 45 $-50,1989$. 
13) Yoneyama, T., Doi, H., Hara, M. and Hamanaka, H.: Influences on mechanical properties of pure titanium casting. Part 2 Silica, magnesia and zirconia investments, Report of the Institute for Medical \& Dental Engineering 24 : 11-15, 1990. (in Japanese)

14) Miyazaki, T. : Recent advances in investment materials for titanium castings, Transactions of second international congress on dental materials, 107-116, 1993.

15) Hashimoto, H., Kuroiwa, A., Wada, K., Hibino, Y., Kouchi, H., Hashimoto, T., Hasegawa, Y., Ando, Y. and Akaiwa, Y.: Reaction product on the surface of titanium castings, Recent advances in investment materials for titanium castings, $J$ J Dent Mater 11 (4) : 603-614, 1992. (in Japanese)

16) Watanabe, K., Okawa, S., Miyakawa, O., Nakano, S., Honma, H., Shiokawa, N. and Kobayashi, M. : Relationship between titanium flow and casting contamination caused by mold materials, $J \mathrm{~J}$ Dent Mater 11 (4) : 662-671, 1992. (in Japanese)

17) Tamaki, Y., Miyazaki, T., Matsuda, S. and Matsubara, N.: Titanium cast with an argon gas pressure and arc melting, $J$ J Dent Mater 12 Special 22 : 162-163, 1993. (in Japanese)

18) Matsuda, S., Matsubara, N. and Miyazaki, S.: The precisely casting method of titanium piece for dental surgery, J J Dent Mater 12 Special 22: 100-101, 1993. (in Japanese) 
HEMA プライマーへの各種銅塩の添加効果を検討し た。ウシ象牙質表面を $10 \%$ リン酸水溶液で処理した後, 銅塩を含む $35 \%$ HEMA 水溶液プライマーを塗布し， MMA-TBBレジンでアクリル棒を接着した。銅塩の種 類・濃度を変えて接着したところ，プライマー中の銅塩 の最適濃度は 0.5-3.0 $\mu \mathrm{mol} / \mathrm{g}$ であった。検討した 8 種類 の銅塩の中で, 硫酸, メタクリル酸, メタクリロイルオ キシエチルフタル酸, メタクリロイルオキシエチルコハ
ク酸の銅塩が特に有効であり,14.2-16.1MPa の平均接着 強さおよび最低の接着強さの平均值として 9.9-11.7MPa が得られた。これらの接着強さは，市販の 4-META/ MMA-TBBレジン接着システムで得られる值よりも大 きかった.ある種の銅塩存在下で重合したポリ MMAの 分子量が増加したことから，いくつかの銅塩では MMA -TBBレジンに対するその分子量増加効果によって接 着強さが向上したことが示晙された。

\section{光重合コンポジットレジンの重合性に及ぼす光強度の影響 \\ 野本理恵，内田馨子，平澤 忠 \\ 鶴見大学歯学部歯科理工学教室}

照射距離を変化させて得られた種々の光強度で光重合 コンポジットレジンを重合し，硬化深さを初め硬化体内 部の反応率，重合率およびペンダント二重結合量の深さ 方向に対する分布を測定し，これら重合特性に及ぼす光 強度の影響を調べた。照射する照射量（光強度と照射時 間の積）を一定にすると光強度，照射時間に関わらず硬
化深さはほぼ一定の值を示し, 硬化体内部の反応率，重 合率およびペンダント二重結合量の各分布もよく一致し た。硬化深さは照射量の対数で表され，この直線回㷌式 加ら使用した光照射器に対する材料の吸光係数および材 料が硬化するのに必要な照射量（臨界照射量）を求める ことができた。

\section{チタン鋳造におけるガスパージの効果 \\ 田島清司，松田清次郎 ${ }^{1}$, 北島聰幸 ${ }^{1}$ 横山有紀，柿川 宏，小園凱夫 \\ 九州歯科大学歯科理工学講座 ${ }^{1}$ 友和産業(侏技術開発部}

溶解雾囲気と鋳型内のガス清浄化を目的としたダブル ガスパージを特徴として開発されたチタン専用鋳造機を 用い,ダブルパージの効果について検討することを目的 に，溶解室䨌囲気中ならびに純チタン鋳造体中の酸素濃 度分析，鋳造体の硬さ試験および鋳造性試験を行った。 ダブルパージを採用することで溶解雾囲気の極低酸素化 が可能となり, 純チタン鋳造体中の酸素量は他機種に比
ベて著しく低くなった。さらにチタン鋳造体表面の硬さ もパージを採用することで減少した。しかし，鋳造性に 対しては影響はみられなかった。以上の結果から，ダブ ルパージを採用して開発されたチタン鋳造機により酸素 の混入を抑えたチタン鋳造体を作製できることが示され た。 